\title{
新規駐車場への転換特性とそれを考慮した需要予測に関する研究 \\ Parking Demand Forecasting Considering Characteristics of Changing to New Parking Lot
}

\author{
新田 保次*、神田 忠士** \\ by Yasutsugu NITTA,Tadashi KANDA
}

\section{1. はじめに}

駐車問題の深刻さが叫ばれてから久しく、1991 (平成3) 年に「道路法」「「駐車場法」が改正された。 主な改正点の一つに、「駐車場整備に関わる国及び 地方公共団体の責務の明確化」がある。各自治体で は駐車場の整備に関する計画を策定し、その他 種々の対策を講じている。

駐車政策については、駐車場の整備量 (駐車容 量)をどれほどにするのか、という課題がある。従 来の駐車場建設 (=自動車交通) 抑制論にかわって、 近年、都市活動の活性化のための重要な施設とし て駐車場が位置づけられるようになったことから、 駐車場整備と道路整備とのバランスが問われるよ うになったわけである。

国や地方公共団体が駐車場を整備する場合、税 金を原資にするため、正確な駐車需要予測を行い、 無駄のない投資を行う必要がある。また、バスや電 車、地下鉄が運用されている場合、これらの交通機 関を考慮し、都市内での総合交通政策に沿った整 備が必要となる。

\section{2. 研究の目的、方法および既往の研究}

(1) 研究の目的と方法

本研究では、新規駐車場の需要予測手法の開発 をめざして基礎的な研究を行う。特に、1章で示し た観点から、公共駐車場の新設に関わる整備地区 での需要の変化に注目し、非集計モデルで需要予

キーワード：駐車需要、交通行動分析

*正会員 工博 大阪大学助教授 工学部土木工学科

(广 565 大阪府吹田市山田丘 2-1

Tel.06-879-7609 Fax .06-879-7612)

** 学生員 大阪大学大学院工学研究科土木工学専攻

( $=565$ 大阪府吹田市山田丘 2-1

Tel.06-879-7610

Fax .06-879-7612)
測を行うことを目的とする。ここで論じる駐車場 とは、「一時預り駐車場」である。

新規駐車場の供用開始に伴い、既存駐車場や路 上、バスや電車などの他交通機関、他地区からの需 要の移動が起きる (図 1)。本研究ではこれらの移動 を転換と定義し、需要が移動する元を転換源と呼 ぶことにする。さらに、既存駐車場から新規駐車場 への需要の流れ (図1の太い実線矢印)に着目し、こ れを非集計モデルで表現し、新規駐車場の需要を 予測することを試みる。非集計モデルの作成にお いては、地区内の駐車特性を組み込み、非集計モデ ルを用いた駐車場需要予測法について考察する。 これらの手順をフローチャートにすると図 2 にな る。

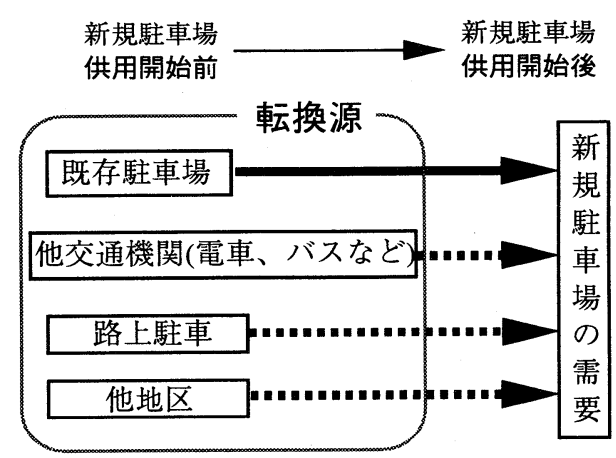

図1転換の考え方

(2) 既往の研究と本研究の位置づけ

ここで、駐車容量拡大に関わる駐車需要予測関 連の主な既往の研究を概観する。

雫石らは “収容台数密度” と入庫台数との回帰分 析から、収容台数を増やしてサービスを高めると 駐車需要が高まることを定性的に示した1)。森村ら は、重力モデルを用いて専用駐車場の共同利用化 に伴う駐車需要の变化の予測を行っている2)。 


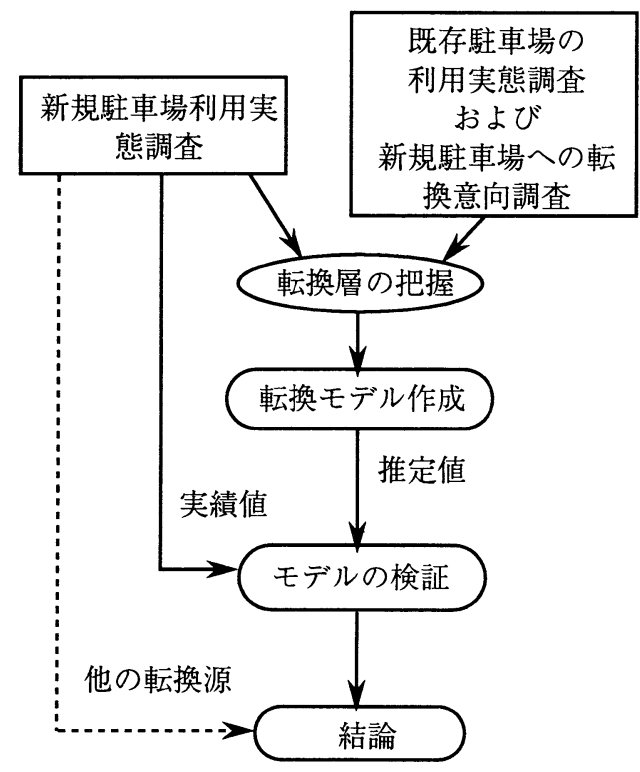

図2 研究のフローチャート

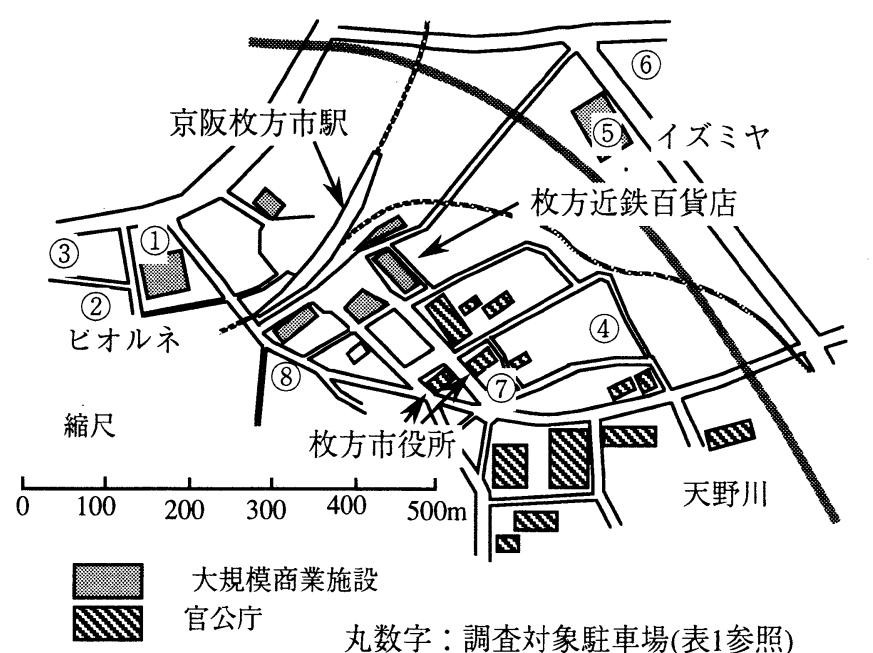

図3 研究対象地区図

表1 調査対象駐車場リスト

\begin{tabular}{c|c|c|c|c}
\hline & 駐車場名 & 付置施設名 & $\begin{array}{c}\text { 駐莗スペ } \\
\text { ース数 }\end{array}$ & $\begin{array}{c}\text { 月平均 } \\
\text { 利用台数 }\end{array}$ \\
\hline (1) & ビオルネ第1立体駐車場 & & 110 & 16900 \\
(2) & ビオルネ西駐車場 & ビオルネ & 75 & 10700 \\
(3) & ビオルネ第2立体駐車場 & & 500 & 14200 \\
\hline (4) & 枚方近鉄駐車場 & 枚方近鉄百貨店 & 350 & 14000 \\
\hline (5) & イスミヤ第1立体駐車場 & イズミヤ & 406 & 48300 \\
(6) & イズミヤ第2立体駐車場 & & 350 & 20400 \\
\hline (7) & 市役所来庁者用駐車場 & 枚方市役所 & 73 & 12200 \\
\hline (8) & 岡東町駐車場 & - & 260 & 10800 \\
\hline
\end{tabular}

これらマクロ的視点の予測に対して、利用者の 意識に基づいた方法がある。長瀬らは AHP法を用 いた駐車場利用台数予測モデルを構築し、新規地 下駐車場の利用台数予測を行っている3)。また、非 集計モデルを用いたものがあるが、このモデルの 長所は、人間の行動原理や意志決定構造を反映す ることが可能で、各種の交通政策のインパクトを 明確に把握できることである ${ }^{4)}$ 。近年、その特性を 生かし、駐車容量拡大も含めた複数の施策 (料金政 策、情報案内、駐車違反取り締まり等) を同時に 行った場合の研究も行われている。

武政らは、買物目的での駐車場選択を扱い、公共 駐車場の容量拡大を含む料金政策、案内システム の導入などに伴う研究対象ブロックへの自動車集 中量の変化を試算している5)。また、高橋らは、購 買地選択の非集計モデルを構築し、駐車場容量の 増加による効果 (自動車集中量の増加)を定量的に 試算している6。塚口らはロジットモデルを中心と した「駐車管理システム」を構築している。 これは、案内システムの導入を主に、専用・ 月極駐車場の弾力的運用、違法駐車の取り締 まり強化などの政策の効果を入庫待ち時間の 短縮、違法路上駐車の削減などで評価するも のである7)。

駐車場の整備により、需要がどのように変 化するのか、他交通との関わりの中でとらえ ることは総合的な交通政策を考える上で重要 である。既往の研究では、新しくできた駐車 場がどのような役割を果たしているのか、需 要はどこから発生しているのか、これらの事 項についての整備後の調査例は少ない。

本研究では需要予測を行う上で、新規駐車 場供用の事前事後で利用者調査を行い、その 結果を予測に取り込むとともに、需要の転換 を利用者の側から捕らえることで総合的な交 通政策立案の観点から駐車場予測を考察するもの である。

\section{3. 既存駐車場の利用特性 \\ (1) 研究対象地区の概要}

本研究対象地区の概要図を図 3 に示す。枚方市 は人口 39 万 7000 人 (1993.5 現在) の大阪府下 5 番 目の規模の典型的な衛星都市であり、その中心部 
を研究対象地区に設定した。この地区の特色は鉄 道駅 (京阪本線枚方市駅) を中心として大小の商業 施設が集中し、さらに官公庁団地が併存している ことと、一時預り駐車場の供給の大半を大規模店 舗がもっていることである。

調査対象一時預り駐車場として、月平均利用台 数 10000 台以上の大規模店舗付置駐車場、岡東町駐 車場 (市営新規駐車場、1994.2.1 供用開始)、および 市役所来庁者用駐車場を選んだ (表 1$)$ 。今回調査対 象となる岡東町駐車場は調査対象地区内一時預り 駐車場の中で唯一の全日一般対象の市営 (公共) 駐 車場となる。

市役所来庁者用駐車場は、平日、市役所に用事の ある人しか利用できないが、土日祝日に 1 回 300 円 で一般に開放している。大規模店舗付置駐車場は、 一定額以上の買物客に対して、90〜120分無料、以 降 50 150円/30 分、それ以外の利用客に対しては 最初の 1 時間 200 400 円、以降 100 200 円/30 分 となっている。これらに対し岡東町 (新規) 駐車場 は最初の 1 時間 300 円、以降 200 円 $/ 30$ 分となって おり、駐車料金の割引制度はない。

\section{(2) 調査概要}

新規駐車場の供用開始直前と供用開始から約 1 年 後の 2 回にわたり、駐車場の利用者に対してアン ケート調査を行った。調査概要は表 2 に載せる。

既存駐車場利用実態調査では、特に、新規に供用 される駐車場に対する利用意向や新規駐車場の駐

表2 調査概 要

\begin{tabular}{|c|c|c|}
\hline & $\begin{array}{l}\text { 既存駐車場 } \\
\text { 利用実態調査 }\end{array}$ & $\begin{array}{l}\text { 新規駐車場 } \\
\text { 利用実態調査 }\end{array}$ \\
\hline 対象駐車場 & (1) $\sim$ (7) & (8) \\
\hline 実施日時 & $\begin{array}{l}\text { 平日： } \\
\text { 1994/1/24(月) } \\
\text { 休日： } \\
\text { 1994/1/23(日) }\end{array}$ & $\begin{array}{l}\text { 平日： } \\
\text { 1995/1/23,30(月) } \\
\text { 休日 : } \\
\text { 1995/1/22,29(日) }\end{array}$ \\
\hline $\begin{array}{l}\text { 主な調査 } \\
\text { 項目 }\end{array}$ & $\begin{array}{l}\text { 利用目的、目的 } \\
\text { 地、駐車時間、岡 } \\
\text { 東町駐車場の利用 } \\
\text { 意向、評価 }\end{array}$ & $\begin{array}{l}\text { 利用目的、目的 } \\
\text { 地、駐車時間、岡 } \\
\text { 東町駐車場完成前 } \\
\text { の利用交通手段 }\end{array}$ \\
\hline 調查方法 & 手渡し配布：郵送回収 & 手渡し配布：郵送回収 \\
\hline $\begin{array}{l}\text { 回収数 } \\
\text { (回収率) }\end{array}$ & $\begin{array}{l}\text { 平日：648(28.2\%) } \\
\text { 休日：969(29.7\%) }\end{array}$ & $\begin{array}{l}\text { 平日：81(20.0\%) } \\
\text { 休日：84(20.0\%) }\end{array}$ \\
\hline
\end{tabular}

車料金、立地、収容台数に対する評価を聞いた。 （3）既存駐車場の利用実態

既存駐車場の利用者実態調査の結果、図4に示す ように、市役所が閉庁している休日の市役所来庁 者用駐車場を除いて、付置している施設のみに出 かけている利用者が多いことが分かった。また、累 積選択率を目的地の数としてみると、大規模店舗 付置系駐車場は休日になると平日よりも累積選択 率が低く(つまり利用者 1 人あたりの目的地の数が 少なく)、逆に市役所来庁者用駐車場は休日の方が 平日よりも累積選択率が高い(つまり利用者 1 人あ たりの目的地の数が多い)ことが分かった。

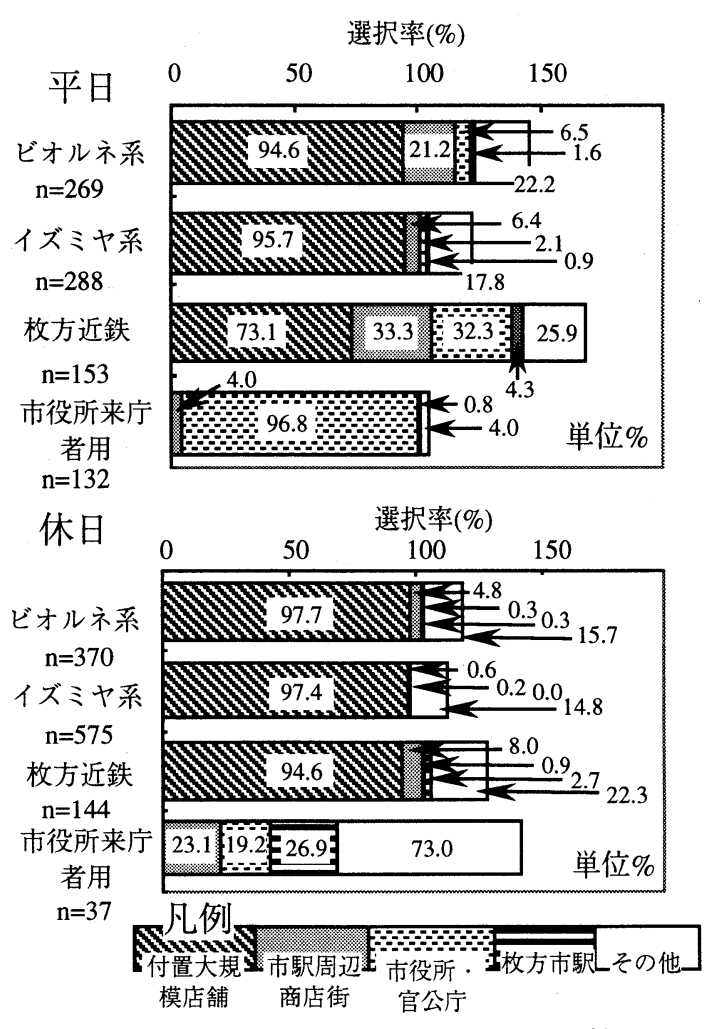

図4 駐車場利用の目的地(複数回答)

（4）新規駐車場への転換特性

既存駐車場の利用者実態調査 (表 2 参照、新規駐 車場供用開始直前実施)の中で、新規駐車場に対す る利用意向を聞いてみた。次に利用意向のある人 のうち、「どこにいく場合に利用したいですか」と いう質問から得た、新規駐車場を利用する上での 仮想の目的地と、既存駐車場を利用したときの実 際の目的地とが一致する人に対して、既存駐車場 から新規駐車場へ「転換意向がある」と判断した。 
こういった転換意向を外的基準にして数量化 II 類 分析を行った。

分析の結果を図5に示す。利用駐車場の影響が一 番大きく、以下駐車時間、新規駐車場の場所や駐車 料金に対する評価、目的地の構成 (付置施設のみか それ以外に目的地を持つか) という要因が続く。目 的地に関して、既存駐車場では付置施設のみにし か目的地を持たない利用者が多く(図4)、付置施設 以外に目的地を持つ利用者の方が転換意向が高い ことから (図 5)、新規駐車場への転換が期待できる 利用者層について、「駐車割引がなくて、目的地が 枚方市駅およびその周辺にある利用者」、駐車割引 を受けているが、目的地が付置施設も含めて複数 ある利用者」の 2 つ層があると予想した。

\section{4. 新規駐車場の利用実態調査}

（1）新規駐車場の利用動向

新規駐車場の1日平均利用台数を月別に追ってみ ると、供用開始直後の 1994 年 2 月は日平均 61 台 / 日 (回転率 0.24$)$ と少なかったものの、その後は知 名度が高まったためか、翌 3 月は 126 台/日 (回転 率0.48)、半年後の 8 月は 257 台/日 (回転率 0.99 ) と 増加している。1995 年 4 月〜10月までの平均をと ると 325 台/日 (回転率 1.35) になっている。大規 模店舗付置系駐車場の平均回転率（各駐車場の回 転率の平均）が平日 1.88 、休日 4.06 であることを考 えると新規駐車場の利用についてまだ余裕がある といえよう。

\begin{tabular}{|c|c|c|c|c|c|}
\hline アイテム & カテゴリー & & 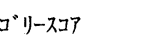 & $\begin{array}{l}\text { カテロ゙" } \\
\text { レシジ }\end{array}$ & $\mathrm{t}$ 值 \\
\hline 利用駐車場 & $\begin{array}{l}\text { ビオルネ } \\
\text { 近鉄 } \\
\text { イズミヤ } \\
\text { 市役所来庁者 }\end{array}$ & & 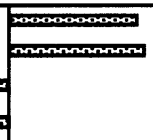 & 1.959 & $\begin{array}{l}18.80 \\
* *\end{array}$ \\
\hline 目的地構成 & $\begin{array}{l}\text { 付置施設のみ } \\
\text { 付置施設以外含む }\end{array}$ & & sos & $\begin{array}{r}0.249 \\
5\end{array}$ & $*^{2.10}$ \\
\hline $\begin{array}{c}\text { 駐車場の選 } \\
\text { 択理由 }\end{array}$ & $\begin{array}{l}\text { 駐車料金が安く } \\
\text { なるから } \\
\text { 目的地に近く } \\
\text { なるから } \\
\end{array}$ & & & $\begin{array}{r}0.144 \\
8\end{array}$ & 1.44 \\
\hline 出発地 & $\begin{array}{l}\text { 市内 } \\
\text { 市外 }\end{array}$ & & $\infty$ & $\begin{array}{r}0.222 \\
6\end{array}$ & 1.52 \\
\hline 駐車時間 & $\begin{array}{l}\sim 0.5 \mathrm{hr} \\
0.5 \sim 1.0 \mathrm{hr} \\
1.0 \sim 1.5 \mathrm{hr} \\
1.5 \sim 2.0 \mathrm{hr} \\
2.0 \mathrm{hr} \sim\end{array}$ & 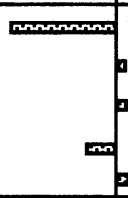 & 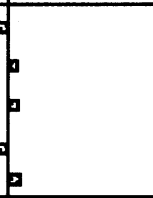 & 0.630 & ${ }^{2.54}$ \\
\hline $\begin{array}{l}\text { 割引制度利 } \\
\text { 用の有無 }\end{array}$ & $\begin{array}{l}\text { 利用した } \\
\text { 利用しなかった }\end{array}$ & & 9 & $\begin{array}{r}0.096 \\
9\end{array}$ & 0.54 \\
\hline $\begin{array}{l}\text { 自動車での } \\
\text { 来訪頻度 }\end{array}$ & $\begin{array}{l}\text { 週3,4日以上 } \\
\text { 週1,2日 } \\
\text { 月2,3日以下 }\end{array}$ & & 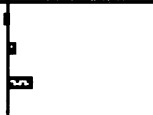 & $\begin{array}{r}0.190 \\
7\end{array}$ & 1.31 \\
\hline $\begin{array}{l}\text { 岡東駐車場の } \\
\text { 場所の評価 }\end{array}$ & $\begin{array}{l}\text { 便利·やや便利 } \\
\text { どちらともいえない } \\
\text { 不便·やや不便 }\end{array}$ & $=$ & 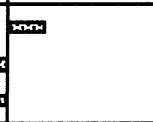 & $\begin{array}{r}0.374 \\
3\end{array}$ & ${ }^{3.51}$ \\
\hline $\begin{array}{l}\text { 岡東駐車場の } \\
\text { 駐車料金の } \\
\text { 評価 }\end{array}$ & $\begin{array}{l}\text { 安い·やや安い } \\
\text { ふっj } \\
\text { 高い·やや高い }\end{array}$ & & $\begin{array}{r}\text { 右隅: } \\
* * \\
* \\
*\end{array}$ & $\begin{array}{l}0.233 \\
\text { 位 } \quad 4 \\
\text { t検定 } 1\end{array}$ & $\begin{array}{l}{ }^{*} .21 \\
\text { 有意 } \\
\text { 有意 }\end{array}$ \\
\hline
\end{tabular}

(2) 調査概要

新規駐車場の利用実態調査は供用開始約 1 年 後に行った (表 2)。調査項目は先の既存駐車場 利用実態調査に準じているが、需要の転換源を 調べるために新規駐車場の供用開始以前の駐車 場所や利用交通手段についての質問項目を加え た。

\section{(3) 利用特性と転換源}

前章では既存駐車場の利用実態調査および転 換意向の要因分析から、新規駐車場の利用者像 を予想した。これを目的地について、新規駐車 場の利用実態調査結果とつき合わせてみる。

新規駐車場の利用者の目的地をみると、平日 は駅周辺の商店街やステーションモールの他、 (人)

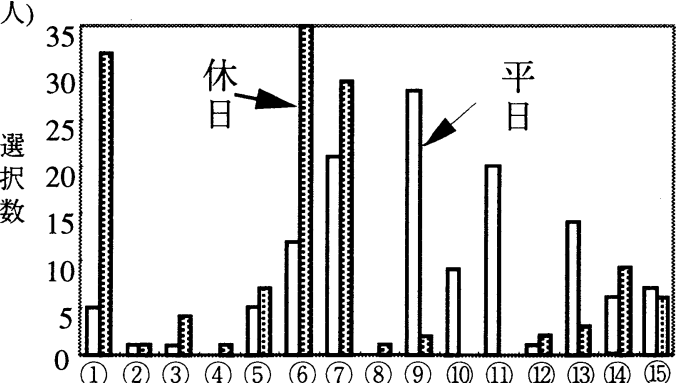

\begin{tabular}{|c|c|c|c|}
\hline \multicolumn{2}{|c|}{ 外的基準 } & スコア平均 & 相関比 \\
\hline 新規駐車場への & 転換したい & 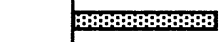 & 0.370 \\
\hline 転換意向 & 転換したくない & 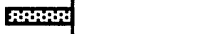 & \\
\hline
\end{tabular}

図5 既存駐車場利用者に対する数量化 II 類分析
ビ三長イ近ス駅ィ銀市官市医枚そ オ越崎ズ鉄テ周ズ行役公民療方の ル 屋ミ辺ミ立所庁会機市他 ネヤ 当商周館関 モ店辺 | 街 儿分類項目

図6 目的地分類(複数回答) 
銀行、病院、官公庁といったように多様性がある が、休日はビオルネ、駅周辺の商店街とステーショ ンモールへの利用者が大半を占めることが分かっ た (図6)。前章で予想したことは、平日は合ってい るといえるが休日は予想と異なっていることが分 かった。つまり、新規駐車場は、平日、大規模店舗 以外の目的地への用事に用いられているが、休日 は近くの大規模店舗 (ビオルネ、ステーションモー ル) への利用者が集中することである。

ここで、新規駐車場への転換源をアンケートで 調べてみると、ビオルネ系駐車場が平日に比べて 休日が急増しており (図 7)、新規駐車場の選択理由 をみると、休日で混雑に関する指標が多くなって いる (図 8)ことが分かった。つまり、休日になる

構成比

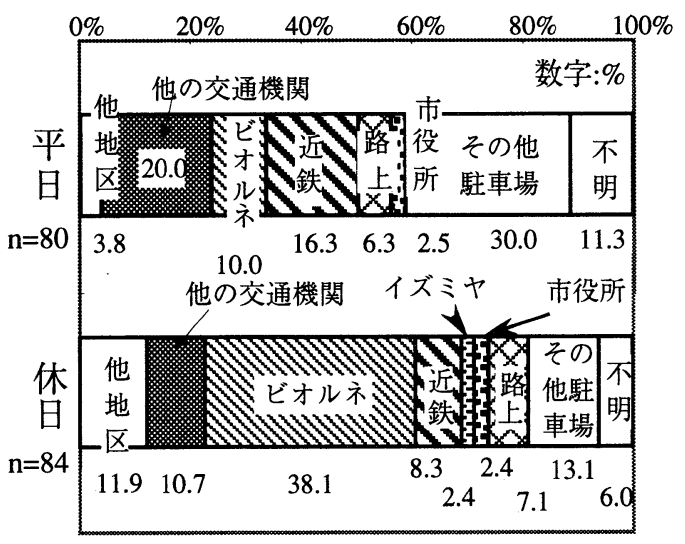

図7 新規駐車場の転換源

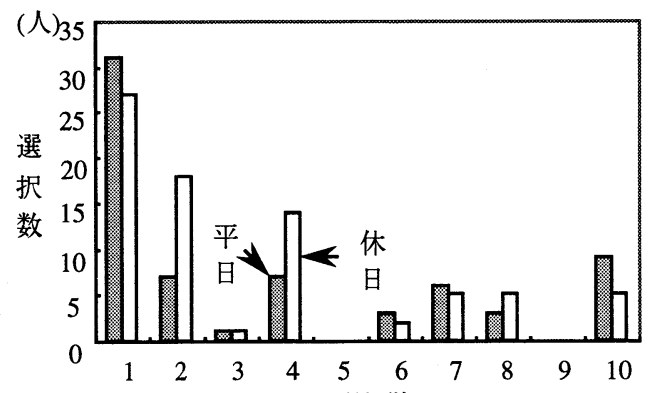

$1:$ 目的地に近いから 選択肢

$2:$ 他の駐車場が混んでいるから

$3:$ 他の駐車場が閉まっているから

$4:$ 入庫するときに待ち時間が少ないから

$5:$ 雨が降っても濡れないから

6: 駐車スペースや通路が広く車の操作が楽だから

7 : 周辺の路上で警察の駐車違反の取り締まりがあるから

8: 防犯の管理が行き届いていて安心して駐車できるから

9:荷物が多いから

10 :その他

図8 岡東町駐車場を選んだ理由(第一理由)
とビオルネ系駐車場での混雑を嫌った利用者が新 規駐車場に回ってくると考えられる。ここに平日 と休日の新規駐車場の利用特性の差が現れるとい える。

また、既存駐車場以外の他交通機関、他地区から の転換も $20 \%$ 強存在することが確認された。

\section{5. 転換モデルの構築と転換需要予測}

(1) 前提と方法

本章で構筑する需要転換モデルは、図1の太い実 線矢印にあたる既存駐車場から新規駐車場への転 換のみを対象とする。

既存駐車場の利用者の中に、新規駐車場への転 換が期待できる層があると想定し、それらの層の うちどれくらい新規駐車場に転換するのかをモデ ルを使い予測を行う。

(2) モデルの構築

モデルの構築には、2 項選択 (既存駐車場と新規 駐車場) のロジットモデルを用いる。

$$
\mathrm{P}_{\mathrm{S}}=\frac{\exp \left(\mathrm{U}_{\mathrm{S}}\right)}{\exp \left(\mathrm{U}_{\mathrm{S}}\right)+\exp \left(\mathrm{U}_{\mathrm{K}}\right)}=\frac{1}{1+\exp \left(\mathrm{U}_{\mathrm{K}}-\mathrm{U}_{\mathrm{S}}\right)}
$$

$\mathrm{P}_{\mathrm{S}}:$ 新規駐車場を選ぶ確率

$\mathrm{U}_{\mathrm{s}}:$ 新規駐車場の効用関数

$\mathrm{U}_{\mathrm{K}}$ : 既存駐車場》効用関数

$$
\mathrm{U}_{\mathrm{K}}-\mathrm{U}_{\mathrm{S}}=\sum_{\mathrm{i}=1} \alpha_{\mathrm{i}}\left(\mathrm{x}_{\mathrm{iK}}-\mathrm{x}_{\mathrm{iS}}\right)
$$

$\alpha_{i}$ : 変数 $\mathrm{i}$ に対応するパラメーター

$\mathrm{x}_{\mathrm{iK}}$ : 既存駐車場に対応する変数 $\mathrm{i}$ の值

$\mathrm{x}_{\mathrm{iS}}$ : 新規駐車場に対応する変数 $\mathrm{i}$ の值

3 章の数量化 II 類分析 (図 5)、4 章の転換源 (図 7) と新規駐車場の選択理由 (図 8) の分析から、平 日、休日別々のモデルを構築することにした。ま た、ロジットモデルの効用関数には、目的地構成 (付置施設のみかそうでないか。平日のみ) 、待ち時 間（休日のみ）、新規駐車場の立地に関する評価 （平日、休日とも）を加えた。

平日、休日どちらも的中率はやや良好である。ま た、尤度比、パラメーターの $\mathrm{t}$ 検定 (平日モデルの 距離 2 乗值の差を除く)、 $\chi^{2}$ 検定結果は統計的に信 頼性のある事を確認した (表3)。平日モデルで、料 
表3 モデルのパラメーター推定

\begin{tabular}{|c|c|c|}
\hline 効用項 & 平日 & 休日 \\
\hline $\begin{array}{l}\text { 新規駐車場の場所に関する評価 } \\
\text { (便利·やや便利 }=1 、 そ の \text { 他 }=0 \text { ) }\end{array}$ & -0.3947 & -0.3311 \\
\hline $\mathrm{t}$ 值 & $* * 2.96$ & $* * 3.71$ \\
\hline ビオルネダミー ， t值 & $\begin{array}{c}1.0064 \\
* * 4.41\end{array}$ & \\
\hline 近鉄ダミー & $\begin{array}{c}1.4535 \\
* * 6.75 \\
\end{array}$ & \\
\hline イズミヤダミー & $\begin{array}{l}-0.5895 \\
* *-3.48\end{array}$ & \\
\hline 定数項(既存=1、新規=0) & & $\begin{array}{r}1.4762 \\
* *-7.98\end{array}$ \\
\hline $\begin{array}{l}\text { 目的地構成 } \\
(\text { 付置施設のみ=1、付置 } \\
\text { 施設以外含む }=0)\end{array}$ & $\begin{array}{l}0.3003 \\
*-2.08\end{array}$ & \\
\hline 待ち時間(分) & & $\begin{array}{r}-0.0666 \\
*-2.08\end{array}$ \\
\hline 距離差(10m) & & $\begin{array}{r}-0.0480 \\
* *-6.66 \\
\end{array}$ \\
\hline 距離2乗値の差(10m) & $\begin{array}{r}-0.0007 \\
-1.87\end{array}$ & \\
\hline 駐車料金差(100yen) & & $\begin{array}{l}-0.0007 \\
* *-2.67 \\
\end{array}$ \\
\hline 的中率 & $78.0 \%$ & $75.0 \%$ \\
\hline$\rho^{2}$ & 0.3916 & 0.2108 \\
\hline $\operatorname{mean} \rho^{2}$ & 0.3718 & 0.2007 \\
\hline$\chi_{0}{ }^{2}=-2 \times(\mathrm{L}(0)-\mathrm{L}(\theta))$ & $* * * 237.24$ & $* * * 208.64$ \\
\hline 対象者数 & 437 & 714 \\
\hline
\end{tabular}

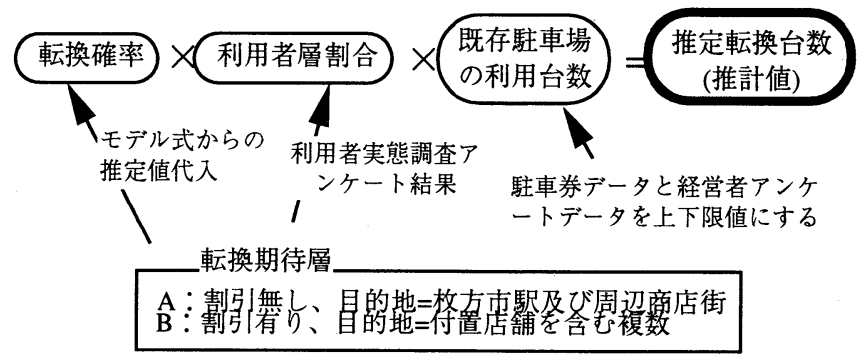

図9 各駐車場からの推定転換台数算出式

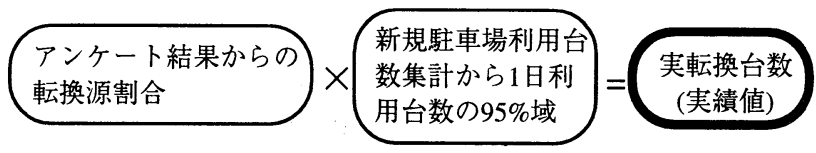

図 10 各駐車場からの実転換台数算出式

金については、t值が 1.0 未満のために変数として採 用しなかった。また、目的地までの距離差について は、平日の場合、休日と比べて待ち時間もそれほど なく、容易に入庫できる状況なので、距離差により 敏感に反応すると考えられる。それで距離值の2乗 を用いた。しかし、 $\mathrm{t}$ 值が 1.50 を超えたものの $5 \%$ 有 意の 1.96 には満たなかった。

(3) 予測結果と実績值との比較

次に、3章で予想した「転換が期待できる利用者 層」ごとにモデルの転換確率を求め、利用者層ごと の利用台数をかけ、推定転換台数を算出する。転換 実台数は、4章で出した転換源構成比と新規駐車場 の利用台数とを掛け合わせて求める (図9,10)。これ ら2つの值を比較検討した結果、推定值が実績值の 1/2〜2 倍の值を持つことが分かった (図 11)。

(台/日)

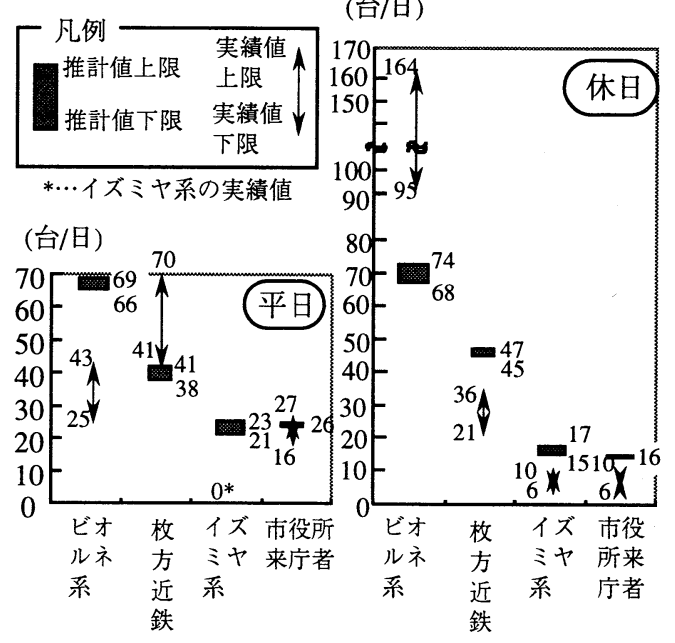

図11 実績值と推計值との比較

各駐車場ごとに詳しくみていく。

(a) ビオルネ系駐車場

平日は推定値が実績值の2倍の值を持ち、休日は 推定值が実績值の半分になっている。通常意識 データによる予測值の方が実測值より大きくなる が、休日では実績值の方が推計值を上回った。この 理由には休日の駐車場の混み具合がモデルにより 適確に反映されていないところに原因があると思 われる。

(b) 枚方近鉄駐車場と市役所来庁者用駐車場

平日の予測結果をみると、他の駐車場より結果 はよいといえる。目的地について言えば、平日の枚 
方近鉄駐車場は、付置店舗を目的地とする利用者 の割合が他の駐車場と比べて相対的に低く、図4に 示すように、市駅周辺商店街の利用者が多い点で 岡東町 (新規) 駐車場の使われ方に似ていると考え られる。そのため、良い予測結果が出ていると推測 できる。これは休日の市役所来庁者用駐車場につ いても同じことがいえる。

なお、休日の枚方近鉄駐車場の予測結果は、推定 值が実績値のおよそ2倍になっている。

(c) イズミヤ系駐車場

イズミヤ系駐車場が他の駐車場と一番大きく違 う点は立地が枚方市駅に対して相対的に遠い(直線 距離で第 1 駐車場が約 $350 \mathrm{~m}$ 、第 2 駐車場が約 $450 \mathrm{~m}$ ) ことである。モデルでは徒歩限界距離についての 考慮がなく、枚方市駅からイズミヤまでの距離が、 徒歩限界距離に近いことも過大予測 (特に平日)の 一因と考えられる。

当然のことながら、新規駐車場供用開始前の利 用意向意識と供用開始後の利用行動では、ずれが 生じるが、このずれに意識と行動のずれによる一 定の法則が見いだせれば意味がある。この分析で は、このずれにより図11のようなパターンが表れ たと指摘できる。今後、推計值と実績值の間に共通 の傾向を見いだすためには、駐車場の混雑度をよ り適確に反映したモデルの作成が必要となろう。

\section{6. 結論と課題}

駐車場需要予測のため、既存駐車場から新規駐 車場への転換モデルに地区の駐車特性を取り込む ことを試みた。主な結論は以下の通りである。

(1) 既存、新規各駐車場の利用実態調査の結果をみ ると、平日は駐車施設を持たない商業施設や医 療施設などの利用者が新規駐車場を利用し、休 日は既存駐車場の混雑のために利用者が新規駐 車場にまわるという駐車特性が明らかになった。

(2) 転換需要を非集計モデルで予測した。利用者の 目的地特性が新規駐車場と良く似ている既存駐 車場からの転換台数予測については相対的に良 い結果が得られた。

(3) 一方、新規駐車場への転換源を駐車場利用の側 から明らかにした。調査対象の既存駐車場以外 の他交通機関、他地区からの転換も20\%強存在
することが確認された。

ところで新規公共駐車場の立地は、現時点の駐車 場容量の不足に対応するという面と地域の活性化の ための新たな需要層を開拓するという面がある。本 論では前者の点を考慮し需要予測の方法を示した点 に意義があろう。ただ需要予測のために作成した駐 車場転換モデルはまだ改良の余地がある。今後の課 題をあげれば以下の通りである。

(1) モデル構築において、本研究では、駐車場の立 地に関する指標に利用者の主観を用いた。これ を歩行環境や周辺の道路事情といった客観的指 標に置き換えることでモデルの精度向上、汎用 化がはかられると考えられる。

(2) 非集計モデルの効用関数の構成について、まず 指標の選定で、地区の駐車、交通特性を十分考 慮する必要がある。例えば、休日モデルでの混 雑指標をうまく取り込むこと、また、平日モデ ルでは、距離項を妥当なものにすることである。

(3) 新規駐車場の全体の需要予測には、交通手段と の同時選択モデルや他の需要予測手法との組み 合わせの検討を必要とする。

\section{7.おわりに}

今回の研究で、枚方市役所交通計画課と（株）宮 内計画技研コンサルタントの宮内 衞氏に多大な協 力と助言をいただいた。記して感謝の意を表する。

\section{《参考文献》}

1) 零石 和利、長瀬 惠一郎、松本 昌二：都市 別駐車需給と利用効率からみた駐車場計画の課 題, 土木計画学研究・講演集 No.16 (1),pp213 218,1993

2) 森村 茂雄、尹 祥福、中川 義英、水野 照 夫：多摩センター地区における共同利用駐車場 の需要予測に関する研究, 土木学会第 49 回年次 学術講演会,pp372 373,1994

3) 長瀬 惠一郎、中野 裕成、松本 昌二：中心 商業地における駐車場の選好構造と需要予測, 土木計画学研究·論文集 No.10,pp255 262,1992 4) 土木学会: 非集計モデルの理論と実際,pp10,1995

5) 武政 功、原田 昇、毛利 雄一：休日の買物 行動における駐車場選択に関する研究, 日本都 市計画学会学術研究論文集 (第22 回),pp523 
528,1987

6) 高橋 洋二、芦沢 哲蔵、佐藤 好男 : 再開発 と駐車場整備の効果分析に基づく地方中心商業 地活性化のための計画策定事例 , 日本都市計画
学会学術研究論文集 (第 27 回),pp469 474,1992

7) 塚口 博司、西海 茂洋：駐車行動分析に基づ いた駐車管理システムに関する研究, 土木学会 論文集 No.500/ IV -25,pp31〜39,1994

新規駐車場への転換特性とそれを考慮した需要予測に関する研究

新田 保次、神田 忠士

新規駐車場の供用開始の事前と事後の2回にわたって駐車場利用実態調査を行い、研究対象地区の 駐車場利用特性および新規駐車場への転換要因を抽出した。それらの特性を考慮して新規駐車場の需 要予測を行った。主な結論は以下の通りである。

1)平日と休日では官公庁の閉庁もあり、駐車場の利用特性と新規駐車場への転換要因に大きな差異が

あることが明らかになった。

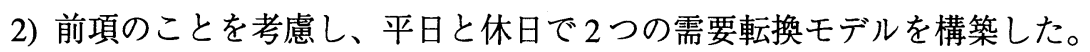

3) 新規駐車場の転換源を調べたところ、既存駐車場以外にバスや電車などの他交通機関、他地区、路 上からの転換が確認された。

Parking Demand Forecasting Considering Characteristics of Changing to New Parking Lot by Yasutsugu NITTA,Tadashi KANDA

This paper aims to clarify the characteristics of changing parking demand to new parking lot,and to build the parking demand forecasting method considering its characteristics. Finally,we have obtained the following main results.

1) The characteristics of parking demand on week-day deffers from it on week-end.

2) Considering the difference, two types of binary logit model have been built.

3) On the other hand,it has been clarified that more than one of fifth demand of new parking lot was moved from other transportations and other areas. 